\title{
EFFECT OF USING SILAGE FROM A MIXTURE OF BERSEEM (EGYPTIAN CLOVER) AND PANICUM MOMBASA ON PRODUCTIVE AND REPRODUCTIVE
} PERFORMANCE OF ZARAIBI KIDS GOATS

Sadek, W. M. A. ${ }^{1}$; M. E. El-Kholany ${ }^{1}$; M. A. Aboul-Omran ${ }^{1}$; Mona E. Farag ${ }^{1}$; M. A. E. Ali ${ }^{1^{*}}$ and Sh. A. Aboelgoud ${ }^{2}$

1- Animal Production Research Institute, Agricultural Research Center, Dokki, Giza, Egypt

2- Forage Crops Research Department, FCRI, Agricultural Research Center, Dokki, Giza, Egypt

\section{1*E-mail: drmamdouh_ali@yahoo.com}

Key Words: Panicum Mombasa, Zaraibi kids, intake, digestibility, productive and reproductive performance

\section{ABSTRACT}

This research was conducted to study the possibility of using a silage mixture made from Egyptian berseem and Panicum Mombasa on productive and reproductive performance for male Zaraibi goats. Thirty Zaraibi kids aged 5 months and averaged $18.69 \mathrm{~kg}$ live body weight, were divided into three similar groups (ten animals each) according to their ages and weights. Each animal group was randomly fed the following experimental treatments. G1 (control ration): consisted of 50\% CFM + 50\% berseem silage (BS); G2: $50 \% \mathrm{CFM}+$ 25\% BS + 25\% Panicum Mombasa silage (PMS); G3: 50\% CFM+ 50\% PMS. The experimental rations were formulated to caver maintenance and production allowance according to NRC (2007). The results indicated that the highest significant values $(P<0.05)$ of averages as DMI, TDNI, and DCPI were recorded for animals fed mixture silage (G2) followed by the animals fed PMS (G3), while the animals fed BS (G1) recorded the lowest values. The animals fed mixture silage $(\mathrm{G} 2)$ recorded higher digestibility values of all nutrients and nutritive values expressed as TDN than those animals fed BS or PMS alone (G1 and G3). Concerning, nutritive values expressed as DCP, it could be noticed that animals fed mixture silage (G2) or BS (G1) recorded significantly higher $(P<0.05)$ than those animals fed PMS (G3). All measured blood constituents of kids (protein, albumin, globulin, urea-N, glucose, and creatinine) were not significantly affected by the inclusion of Panicum in tested diets. The results also showed the experimental group fed (G2) appeared improved daily gain and feed conversion expressed as $\mathrm{Kg}$ DM and TDN intake $/ \mathrm{kg}$ gain compared with other treatments. On the other hand, the obtained results indicated no significant differences in respiration rate, pulse, and rectal and skin temperatures. Also, the results indicate that the animals which high-levels of feed intake (G2) had significantly higher values of Scrotal circumference (SC) and Testicular volume 
(TV). It also found that using silage a mixture made from B and PM in diets of growing male Zaraibi goats was the best economic efficiency.

It could be concluded that using Panicum Mombasa in any form has a positive effect on the productive performances of kids goats, especially when mixed with different green legumes forages as an Egyptian clover, in terms of dry matter intake, digestibility, and feeding value, the feed utilization efficiency of forage into daily gain, and economic efficiency makes it a diet of choice for production and reproduction.

\section{INTRODUCTION}

The farm animals in Egypt suffer from a shortage of feed, especially during the summer season and the green forage is cheap food for the feeding of ruminants, the importance of new green forages depends on high yield and its quality, especially in reclaimed soils. Several attempts have been made to introduce a new high-yielding green grass fodder with high protein content such as Panicum Mombasa (PM), is considered one of the most valuable forages plants, with high leaf and seed production and very palatable to livestock and contains high crude protein, essential vitamins, minerals, and amino acids, and resistance to the pests such as Deois sp., Zulia entreriana, and Mahanarva fimbriolata and it can be mixed with green leguminous forages to form mixtures with a higher nutritional and economic value and available all year round (Jank et al., 2013). It's successfully mixed with legumes (Humphreys and Patridge, 1995). Du Ponte et al. (1998) demonstrated that Guinea grass (Panicum max) can be successful silage while maintaining nutritional quality and minimal spoilage under Hawaiian climatic conditions. Panicum maximum is considered one of the most valuable fodder plants, with high leaf and seed production and very palatable to livestock. There is a need to supplement Panicum maximum with other forages that have high nutritive value and available all year round. Leaves are noted for high crude protein, essential vitamins, minerals, and amino acids (Makkar and Becher, 1997; Gidamins et al., 2003). In addition to these benefits, Refaie, et al. (2020) showed that the chemical composition of the Spanish Panicum Mombasa was $11.65 \%$ crude protein, $2.67 \%$ crude fat, and $30.66 \%$ crude fiber, amino acids methionine $0.16 \%$, lysine $0.49 \%$, valnine $0.48 \%$, alanine $0.61 \%$, glycine $0.39 \%$, serine $0.32 \%$, cyateine $0.21 \%$, glutamic $0.98 \%$, therionnine $0.34 \%$, aspartic $0.80 \%$, isoleucinec $0.36 \%$, tyrosine $0.32 \%$, phenylaanine $0.45 \%$, histidine $0.18 \%$, argenine $0.45 \%$. Whoever, Yousuf et al. (2007) and Brown and Adjei (1995) reported that sheep fed on Panicum Mombasa grass hay improved their weight gain and feeding efficiency. Also, Wildeus et al. (2007) and Al-Jorani et al. (2020) indicated that there was no significant difference in final weight between the alfalfa hay and Panicum Mombasa treatments, and 
that the alfalfa hay treatment outweighed the Panicum Mombasa treatment in the daily weight gain rate. Furthermore, Bamigboye et al. (2014) found that the using of Panicum Mombasa had positive effects in feed intake, daily weight gain, and feed efficiency. Eyoh et al. (2019) which reported that feeding goats on Panicum Mombasa in different forms (fresh, withered, silage and straw) had no significant effect on final weight, slaughter weight, daily weight gain and feed conversion ratio. The aim of the present study was the evaluation of Panicum as green forage compared with Egyptian berseem and their mixtures as silage in feeding Zaraibi kids and its effect on digestibility, feeding values, some blood parameters, feed conversion, and economic efficiency.

\section{MATERIALS AND METHODS}

This study was carried out at El-Serw Experimental Research Station, Animal Production Research Institute, and Panicum Mombasa (PM) forage and Berseem (Egyptian clover) (B) were obtained from experiment field at El-Serw Agricultural Research Station, Forage Crops Research Department, FCRI, Agricultural Research Center, Ministry of Agriculture.

\section{Experimental animals and feeding}

A feeding trial that lasted 120 days was carried out on thirty Zaraibi kids aged 5 months and averaged $18.69 \mathrm{~kg}$ live body weight, were divided into three similar groups (ten animals each) according to their ages and weights. Each animal group was randomly fed the following experimental treatments. G1 (control ration): consisted of $50 \%$ concentrate feed mixture (CFM) $+50 \%$ berseem silage (BS); G2: $50 \%$ $\mathrm{CFM}+25 \% \mathrm{BS}+25 \%$ Panicum Mombasa silage (PMS); G3: $50 \%$ $\mathrm{CFM}+50 \%$ PMS. The experimental rations were formulated to caver maintenance and production allowance according to NRC (2007).

The B and PM grass was as cut at the pre-flowering stage chopped at about $3 \mathrm{~cm}$ in length and ensiled in three piles holding about 3 tons/pile of the fresh materials. Silage made from $100 \%$ Berseem was prepared by adding $3 \%$ molasses was a mixed will, on a fresh basis (G1), while group (G2) silage made from the mixture 50\% Berseem $+50 \%$ Panicum and finally group (G3) silage made from $100 \%$ Panicum on the fresh basis in prepared without any additives according to Ahmed et al. $(2001 ; 2013)$, and mixed well and pressed to ensure compaction and then sealed to ensure airtight or anaerobic conditions for 40 days. After 40 days, the ensiled materials were opened and samples were analyzed for proximate fractions. The rations were offered in group feeding in two equal portions at $8.00 \mathrm{am}$ and $4.00 \mathrm{pm}$. Water was available at all times and was measured as average for each group. All kids were weighted at the beginning and at the end of the feeding period biweekly. Feeding requirements were adjusted biweekly 
according to weight changes. The digestibility trial was conducted during the end of the experimental by using three animals in each experimental group. A grab sample method was applied using acid insoluble ash (AIA) technique as internal marker according to Van Keulen and Young (1977). Fecal grab sample were collected for four successive days from each animals. Feed intake and conversion were calculated. Chemical composition of the different ingredients, experimental rations and faces samples were analyzed according to the procedures of A.O.A.C. (1995). Chemical analysis of different feedstuffs and calculated rations are presented in table (1). Rectal, Skin temperatures were measured by using certified mercury in glass clinical thermometer with an accuracy of $\pm 0.1{ }^{\circ} \mathrm{C}$. The scrotal circumference (SC) was measured using a cloth tape and measured in centimeters $(\mathrm{cm})$ as the largest diameter of scrotum after pushing the testes firmly into the scrotum. The testes volume $\left(\mathrm{cm}^{3}\right)=0.015409 \times \mathrm{SC} 3$ was determined according to Entwistle (1992). Nine kids ( $\mathrm{N}=3$ /treatment) were randomly chosen to collect blood samples at weaning, $10 \mathrm{ml}$ of blood samples were collected from the jugular vein from each animal into clean tubes. Then, the serum samples were obtained by centrifugation for $30 \mathrm{~min}$ at $3000 \mathrm{rpm}$ and stored at $-18{ }^{\circ} \mathrm{C}$ until the analysis. Stored samples were analyzed for total protein (TP), albumin (AL), urea-N, glucose and creatinine using kids and the methods reported by biochemistry (Biomerieux). Serum total globulin (GL) was calculated by differences (TPAL). The determination was assayed by commercial kits produced by BioMerieux (Craponne, France).

Statistical evaluation of the significant difference between means (mean \pm SEM) were performed by ANOVA followed by the Duncan post hoc test to determine significant differences in all the parameters among all energy addition types using SAS Statistical System package V9.0 (SAS, 2002). The significant differences among means were calculated using Duncan's Multiple Range Test (Duncan, 1955).

\section{Chemical composition of rations:}

\section{RESULTS AND DISCUSSION}

The proximate composition of different ensiled mixtures of PM with $\mathrm{B}$ fed to Zaraibi kids is presented in Table (1). Results showed that highest percentage of $\mathrm{CP}, \mathrm{CF}$ and Ash and lowest percentage of DM, OM, EE and NFE in the ration G1compared with other treatments (G2 and G3). On the other hand, results showed that highest percentage of DM, OM, EE and NFE and lowest percentage of $\mathrm{CF}$ and Ash in the ration G3 compared with other treatments (G1 and G2). While the G2 was the middle between the G1 and G3 in all the chemical composition. Also, data presented in Table (1) showed that highest percentage of DM, OM, EE and NFE and lowest percentage of CF, CP and Ash in the PMS compared with BS. Consequently it is commonly included in rations for growing kids. 
These results were in agreement with those reported by Ajayi $\boldsymbol{e t}$ al. (2012) and Nkosi et al. (2010), probably due to combination of the legumes with grass. This corroborated the findings of Baraza et al. (2009) that different silage types resulted in different nutritional composition. The crude protein levels obtained for the mixtures of grass (PM)/legume (B) silages and sole grass $(\mathrm{BM})$ in this study were higher than $7.0 \mathrm{~g}$ per 100 grams recommended for small ruminants (NRC, 1981) and 10-12 g per 100 grams recommended by ARC (1980). Generally, there are many factors affecting chemical composition as species and varieties of forages, soil, fertilization, subsequent cuts, age, cuts, and environmental condition (Gabra et al., 1991; Van Soest, 1996; Haggag et al., 2000).

Table (1): Chemical analysis \% (on DM basis) of tested rations

\begin{tabular}{|c|c|c|c|c|c|c|c|}
\hline \multirow{2}{*}{ Item } & \multirow{2}{*}{ DM } & \multicolumn{6}{|c|}{ Chemical analysis \% (on DM basis) } \\
\hline & & $\mathbf{O M}$ & $\mathbf{C F}$ & CP & $\mathbf{E E}$ & NFE & Ash \\
\hline CFM & 91.50 & 93.85 & 15.60 & 14.50 & 3.20 & 60.55 & 6.15 \\
\hline BS & 36.84 & 81.57 & 24.73 & 16.44 & 0.91 & 39.49 & 18.43 \\
\hline PMS & 38.67 & 86.66 & 23.68 & 14.87 & 2.83 & 45.28 & 13.34 \\
\hline BS+PMS & 37.91 & 84.05 & 24.55 & 15.42 & 2.04 & 42.04 & 15.95 \\
\hline G1 & 64.17 & 87.71 & 20.17 & $15.47^{\mathrm{a}}$ & $2.06^{\mathrm{c}}$ & $50,01^{b}$ & $12.29^{\mathrm{a}}$ \\
\hline G2 & 64.71 & 88.95 & 20.07 & $14.96^{b}$ & $2.62^{b}$ & $51.30^{b}$ & $11.05^{b}$ \\
\hline G3 & 65.09 & 90.26 & 19.64 & $14.69^{b}$ & $3.02^{\mathrm{a}}$ & $52.91^{\mathrm{a}}$ & $9.74^{\mathrm{c}}$ \\
\hline
\end{tabular}

CFM: $40 \%$ yellow corn grain, $25 \%$ undecortecated cotton seed meal, $22 \%$ wheat bran, $6 \%$ rice bran, $3.5 \%$ molasses, $2.5 \%$ limestone, and $1 \%$ common salt. G1: 50\% CFM + 50\% BS, G2: 50\% CFM +25\% BS + 25\% PMS, G3: 50\% CFM+50\% PMS.

a-b: Means in the same column with different superscripts differ significantly at $(P<0.05)$.

\section{Feed intake and water consumption:}

The average of daily intakes by Zaraibi kids are summarized in Table (2). The highest significantly values $(P<0.05)$ of averages as DMI, TDNI and DCPI were recorded for animals fed mixture silage (G2) followed by the animals fed PMS (G3), while the animals fed BS (G1) recorded the lowest values. Similar results were reported by Gabra and Sherif (1985) who noticed that daily feed intake was significantly higher with sheep fed mixture forage (50\% tritical $-50 \%$ berseem) than that feed tritical or berseem forage alone. Similar results were observed by Shehata et al. (2001), Ahmed et al. (2001) and Ibrahim et al. (2012) with using of mixture silages in small ruminants rations. Also, Ojo et al. (2019) when they fed rams on Panicum and Panicum with the addition of herbaceous forage legume pellets supplements, as they found a significant difference between the treatments in the amount of feed intake. While, These results differed with Adegun and Aye (2013) observed the presence of a significant increase in the amount of feed 
intake between the treatment of rams that fed on Panicum only and treatments that were fed Panicum with the addition of different proportions of cotton seeds and Moringa leaves.

The average daily water consumption of Zaraibi kids fed the tested experimental rations is summarized in Table (2). The differences among the three groups in water consumption $(\mathrm{L} / \mathrm{h} / \mathrm{d}, \mathrm{ml} / \mathrm{kg} \mathrm{LBW}$ and $\mathrm{ML} / \mathrm{g}$ DMI) were not noticeable. Generally, the quantity of daily water consumption in present study is nearly similar to those obtained by Soliman et al. (2010) on growing Zaraibi goats (ranged from 2.22 to 3.30 $\mathrm{ml} / \mathrm{g}$ DM intake) and Ahmed et al. (2013) on lactating Zaraibi goats (ranged from 2.82 to $5.06 \mathrm{ml} / \mathrm{g} \mathrm{DM}$ intake).

Table (2): Average of daily intakes and water consumption by Zaraibi kids fed the experimental rations

\begin{tabular}{|c|c|c|c|}
\hline \multirow{2}{*}{ Item } & \multicolumn{3}{|c|}{ Treatments } \\
\hline & G1 & G2 & G3 \\
\hline \multicolumn{4}{|c|}{ Av. daily DMI g during experimental period: } \\
\hline CFM & 417 & 457 & 430 \\
\hline BS & 440 & - & - \\
\hline PMS & - & - & 451 \\
\hline BS+PMS & - & 495 & - \\
\hline Av. daily DMI, $g$ & $857^{b}$ & $952^{\mathrm{a}}$ & $\mathbf{8 8 1}^{\mathrm{ab}}$ \\
\hline Av. daily TDN, kg & $0.501^{\mathrm{c}}$ & $0.599^{\mathrm{a}}$ & $0.536^{b}$ \\
\hline Av. daily DCP, g & $83.90^{b}$ & $94.53^{\mathrm{a}}$ & $80.17^{\mathrm{c}}$ \\
\hline \multicolumn{4}{|l|}{ Water consumption: } \\
\hline $\mathbf{L} / \mathbf{h} / \mathbf{d}$ & 2.10 & 2.35 & 2.25 \\
\hline ML/kg LBW & 10.44 & 10.51 & 10.89 \\
\hline ML/g DMI & 2.47 & 2.47 & 2.55 \\
\hline
\end{tabular}

a-b: Means in the same row with different superscripts differ significantly at $(P<0.05)$.

\section{Nutrients digestion and feeding values:}

Data of Table (3) clearly indicated that animals fed mixture silage (G2) recorded higher digestibility values of all nutrients and nutritive values expressed as TDN than those animals fed BS or PMS alone (G1 and G3). The digestibility of $\mathrm{CP}$ and $\mathrm{CF}$ most nutrients tended to increase with kids fed BS (G1) compared with kids fed PMS (G3). However, the kids fed PMS (G3) recorded higher $(P<0.05)$ digestibility values of $\mathrm{EE}$ and tended to increase digestibility values of OM and NFE digestibility compared with kids fed BS (G1). This might be due to the increase in chemical analysis values as $\mathrm{CP}$ and $\mathrm{CF}$ for BS (G1) group and also increase in chemical analysis values as EE, OM and NFE for PMS (G3) group (Table 1).

Concerning, nutritive values expressed as DCP, it could be noticed that animals fed mixture silage (G2) or BS (G1) recorded significant higher $(\mathrm{P}<0.05)$ than those animals fed PMS (G3). The improvement in digestion coefficients of most nutrients and nutritive value (TDN) with mixture silage 
may be due to the positive associative effect between the two silages and the better condition of the rumen fermentation. Forage and grass mixtures used could have led to synchronized fermentability of individual chemical constituents leading to associative effects and improvements in DM intake and digestibility (Sinclair et al., 1995; Rosales and Gill, 1997). In the same context, Taye et al. (2017) found that the improvement in most nutrients of digestion coefficients and nutritive value expressed as TDN and DCP with mixture grass and Legumes silage may be due to the positive associative effect between the two silages and improve the condition of the rumen fermentation. These results seem to agree with those mentioned by Gabra (1984); Soliman et al. (1997); Haggag et al. (2002) and Ibrahim et al. (2012) with mixture forage (legume with grass).

Table (3): Digestion coefficients and nutritive values of tested ration fed to male Zaraibi goats

\begin{tabular}{|c|c|c|c|}
\hline \multirow{2}{*}{ Item } & \multicolumn{3}{|c|}{ Treatments } \\
\hline & G1 & G2 & G3 \\
\hline \multicolumn{4}{|c|}{ Digestion coefficients: } \\
\hline DM & $63.50 \pm 0.70^{\mathrm{ab}}$ & $65.12 \pm 0.56^{\mathrm{a}}$ & $61.97 \pm 0.40^{b}$ \\
\hline$\overline{\mathbf{O M}}$ & $64.70 \pm 0.34^{b}$ & $67.20 \pm 0.51^{\mathrm{a}}$ & $65.90 \pm 0.65^{\mathrm{ab}}$ \\
\hline $\mathbf{C F}$ & $55.75 \pm 1.10^{\mathrm{ab}}$ & $57.21 \pm 0.40^{\mathrm{a}}$ & $53.50 \pm 0.62^{b}$ \\
\hline $\mathbf{C P}$ & $63.30 \pm 0.60^{b}$ & $66.35 \pm 0.63^{\mathrm{a}}$ & $61.97 \pm 0.49^{b}$ \\
\hline EE & $73.69 \pm 0.83^{b}$ & $77.40 \pm 0.53^{\mathrm{a}}$ & $76.40 \pm 0.38^{\mathrm{a}}$ \\
\hline NFE & $68.03 \pm 0.30^{b}$ & $72.10 \pm 0.93^{\mathrm{a}}$ & $68.20 \pm 0.62^{b}$ \\
\hline \multicolumn{4}{|c|}{ Nutritive values \%: } \\
\hline TDN & $58.47 \pm 0.61^{b}$ & $62.96 \pm 0.44^{\mathrm{a}}$ & $60.87 \pm 0.30^{b}$ \\
\hline DCP & $9.79 \pm 0.09^{\mathrm{a}}$ & $9.93 \pm 0.09^{\mathrm{a}}$ & $9.10 \pm 0.08^{b}$ \\
\hline
\end{tabular}

a-b: Means in the same row with different superscripts differ significantly at $(P<0.05)$.

\section{Blood parameters:}

The results in Table (4) indicated that all measured blood constituents of Zaraibi kids (protein, albumin, globulin, urea-N, glucose, and creatinine) were not significantly affected by the inclusion of Panicum in tested diets indicating no adverse effects either on blood components or animal health, in general, that could occur as a result of such treatment.

Table (4): Total protein, albumin, globulin, urea-N, glucose and creatinine concentrations blood of Zaraibi kids fed different experimental rations

\begin{tabular}{|c|c|c|c|}
\hline \multirow{2}{*}{ Item } & \multicolumn{3}{|c|}{ Treatments } \\
\hline & G1 & G2 & G3 \\
\hline Total protein, $\mathrm{g} / \mathbf{1 0 0} \mathrm{ml}$ & $6.44 \pm 0.07$ & $6.46 \pm 0.08$ & $6.44 \pm 0.07$ \\
\hline Albumin (A), g/100 ml & $\mathbf{3 . 5 3} \pm 0.03$ & $3.60 \pm 0.07$ & $3.62 \pm 0.07$ \\
\hline Globulin $(\mathbf{G}), \mathbf{g} / \mathbf{1 0 0} \mathrm{ml}$ & $2.99 \pm 0.03$ & $2.86 \pm 0.03$ & $2.82 \pm 0.10$ \\
\hline A/G ratio & $1.18 \pm 0.01$ & $1.26 \pm 0.03$ & $1.28 \pm 0.06$ \\
\hline Urea-N, $\mathrm{mg} / 100 \mathrm{ml}$ & $19.20 \pm 0.70$ & $18.30 \pm 0.50$ & $17.60 \pm 0.80$ \\
\hline Glucose, $\mathrm{mg} / 100 \mathrm{ml}$ & $60.65 \pm 1.40$ & $63.20 \pm 1.03$ & $61.10 \pm 1.85$ \\
\hline Cereatinine, $\mathrm{mg} / 100 \mathrm{ml}$ & $1.50 \pm 0.04$ & $1.40 \pm 0.03$ & $1.35 \pm 0.05$ \\
\hline
\end{tabular}


Also, the obtained results indicated that blood components measured showed a slight difference due to the source of forages, while all levels were within the normal ranges which had been reported by Kaneko (1989) for healthy goats and the line with the finding of Haggag et al. (2002) who used triticale and berseem forage and their mixture in small ruminants rations.

\section{Productive performance:}

Productive performance of the growing Zaraibi kids (Table 5) indicated that kids who fed mixture silage $(\mathrm{G} 2)$ appeared to show higher significant $(P<0.05)$ live body weight and daily gain followed by animals fed PMS (G3), while the lowest one was recorded for (G1) ration. These results may be due to that animals fed G3 consumed high DMI and recorded higher digestibility values of all nutrients and nutritive values as TDN and DCP than those animals fed BS or PMS alone (G1 and G3). Concerning, the feed conversion expressed as the amount intake of DM, TDN and DCP to give one $\mathrm{kg}$ gain are shown in Table (5). The animals fed $(\mathrm{G} 2)$ appeared $(P<0.05)$ better feed conversion expressed as $\mathrm{Kg}$ $\mathrm{DM} / \mathrm{kg}$ gain followed by $\mathrm{G} 3$, while G1 recorded the lowest values. Similarly, the values of feed conversion expressed as TDN intake/kg gain was better of kids fed PMS with BS $(\mathrm{G} 2,2.79)$ compared with those other groups $(\mathrm{G} 1,2.83)$ and $(\mathrm{G} 3,2.88)$, however the significant differences were not found. On the other hand, the animals fed (G1) appeared $(P<0.05)$ better feed conversion expressed as $\mathrm{Kg} \mathrm{DCP} / \mathrm{kg}$ gain followed by G2, while G3 recorded the lowest values. These results are in good agreement with those obtained by Bamigboye et al. (2014) that they found the using of Panicum Mombasa had positive effects in feed intake, daily weight gain, and feed efficiency. Furthermore, Jiwuba et al. (2017) showed in a study on African goats, there was a significant difference $(P \leq 0.05)$ between the treatments, where the treatments fed on Panicum by adding 10 and $15 \%$ of the Moringa leaves were significantly superior $(P \leq 0.05)$ to the treatment fed on Panicum only. On the other hand, Loresco et al. (2019) findings that showed there were no significant differences between calves fed on Panicum and calves fed on different grass, and Eyoh et al. (2019) which reported that feeding goats on Panicum Mombasa in different forms (fresh, withered, silage and straw) had no significant effect on final weight, daily weight gain and feed conversion ratio. The obtained values of the feed conversion expressed as the amount intake of DM, TDN and DCP to give one $\mathrm{kg}$ gain are with the normal range given by Soliman et al. (1997) and Ahmed et al. (2000) for male Zaraibi goats during growing period. In this respect, Ahmed et al. (2003) found that the feed efficiency of Zaraibi kids (ageing from 7-8 months) ranged from 4.31 to $5.92 \mathrm{~kg}$ $\mathrm{DM} / \mathrm{kg}$ gain. 
Egypt. J. of Appl. Sci., 36 (5-6) 2021

Table (5): Productive performance and feed conversion of Zaraibi kids fed the experimental rations

\begin{tabular}{|c|c|c|c|}
\hline \multirow{2}{*}{ Item } & \multicolumn{3}{|c|}{ Treatments } \\
\hline & G1 & G2 & G3 \\
\hline No. of kids & 10 & 10 & 10 \\
\hline Duration of trail, day & 120 & 120 & 120 \\
\hline Av. initial body weight, kg & $18.69 \pm 1.23$ & $18.67 \pm 2.11$ & $18.72 \pm 2.34$ \\
\hline Av. Final body weight, & $21.25 \pm 2.34^{\mathrm{c}}$ & $25.76 \pm 3.12^{\mathrm{a}}$ & $22.30 \pm 3.62^{b}$ \\
\hline Av. daily gain, $\mathrm{g}$ & $177.08 \pm 15.68^{c}$ & $214.67 \pm 18.45^{\mathrm{a}}$ & $185.83 \pm 14.18^{b}$ \\
\hline \multicolumn{4}{|l|}{ Feed conversion: } \\
\hline Kg DM/kg gain & $4.84^{\mathrm{a}}$ & $4.43^{b}$ & $4.74^{\mathrm{ab}}$ \\
\hline Kg TDN/kg gain & 2.83 & 2.79 & 2.88 \\
\hline Kg DCP/kg gain & $0.474^{\mathrm{a}}$ & $0.440^{\mathrm{ab}}$ & $0.431^{b}$ \\
\hline
\end{tabular}

a-b: Means in the same row with different superscripts differ significantly at $(P<0.05)$.

\section{Physiological parameters:}

Physiological response of Zaraibi kids to treatments was expressed as changes in respiration rate (RR), rectum temperature (RT), pulse rate (PR), and skin temperature (ST) as shown in Table (6) as well as the amount of consumed water as presented in Table (2) in comparison with the control group (G1). The obtained results indicated no significant differences in respiration rate, pulse, and rectal and skin temperature. Values detected among tested groups revealed that the animals were in good health condition.

Table (6): The effect of using Panicum and berseem silage in Zaraibi kids rations on physiological parameters

\begin{tabular}{|l|c|c|c|}
\hline \multirow{2}{*}{\multicolumn{1}{|c|}{ Item }} & \multicolumn{3}{|c|}{ Treatments } \\
\cline { 2 - 4 } & G1 & G2 & G3 \\
\hline Respiration rate, $(\mathbf{R R})$ & $\mathbf{2 0 . 5 4} \pm 2.30$ & $\mathbf{1 9 . 7 0} \pm \mathbf{3 . 2 0}$ & $\mathbf{2 0 . 1 0} \pm 2.55$ \\
\hline Pulse rate, $($ PR) & $\mathbf{8 1 . 6 5} \pm 5.80$ & $\mathbf{8 1 . 8 0} \pm 6.02$ & $\mathbf{8 2 . 0 5} \pm 3.90$ \\
\hline Rectum temperature, $($ ST) & $\mathbf{3 8 . 9 0} \pm \mathbf{0 . 2 0}$ & $\mathbf{3 9 . 4 0} \pm \mathbf{0 . 1 6}$ & $\mathbf{3 9 . 6 0} \pm 0.30$ \\
\hline Skin temperature, $($ ST) & $\mathbf{3 8 . 4 0} \pm \mathbf{0 . 3 3}$ & $\mathbf{3 8 . 5 0} \pm \mathbf{0 . 2 0}$ & $\mathbf{3 8 . 5 5} \pm \mathbf{0 . 2 2}$ \\
\hline
\end{tabular}

\section{Puberty}

Puberty age, scrotal circumference, and testes volume were determined of meal Zaraibi kids fed tested rations shown in Table (7). The results indicate that the G2 was the highest DM intake (952 g) followed by G3 (881 g) while G1 was the lowest $(857 \mathrm{~g})$ as shown in Table (2). The meal maintained on a high level of feeding had significantly higher values of SC and TV $(16.12,15.10 \mathrm{~cm}$ and 64.55 , $53.05 \mathrm{~cm}^{3}$ ) G2 and $\mathrm{G} 3$ respectively during the experimental period. The reduction in (SC) with feed less is associated with general loss in the mean BW. The current results are in agreement with Kheradmand $\boldsymbol{e t}$ al. 
(2006) who is found the high SC value with the high feeding level lends support to the hypothesis that the growth of testis can be affected when the animals are fed above their requirement. Similarly, (Mohamed and Abdelatif, 2010; Behery et al., 2014) found that males which received a higher plane of nutrition chiefly energy result in increased sexual hormones so reflected on puberty age.

Table (7): Effect of tested rations on puberty age, scrotal circumference and testes volume

\begin{tabular}{|c|c|c|c|}
\hline \multirow{2}{*}{ Item } & \multicolumn{3}{|c|}{ Treatments } \\
\hline & G1 & G2 & G3 \\
\hline Age, days & $188.2 \pm 1.01^{\mathrm{c}}$ & $167.70 \pm 1.40^{\mathrm{a}}$ & $176.50 \pm 1.22^{b}$ \\
\hline Scrotal circumference $(\mathrm{SC}), \mathrm{cm}$ & $13.51 \pm 0.39^{\mathrm{c}}$ & $16.12 \pm 0.31^{\mathrm{a}}$ & $15.10 \pm 0.40^{b}$ \\
\hline Testicular volume $(\mathrm{TV}), \mathrm{cm}^{3}$ & $37.99 \pm 3.22^{\mathrm{c}}$ & $64.55 \pm 4.11^{\mathrm{a}}$ & $53.05 \pm 7.53^{b}$ \\
\hline
\end{tabular}

a-b: Means in the same row with different superscripts differ significantly at $(P<0.05)$.

\section{Economic efficiency:}

Economic efficiency, estimated as the price of gained weight divided by the cost of feed consumed is presented in Table (8). The data indicated generally that the relative economic efficiency of feeding Zaraibi kids on the different experimental rations show a reduction in feed cost $/ \mathrm{kg}$ gain of animals fed G2 followed by G3, while the highest one was recorded for (G1) ration. From this, it becomes clear that using Panicum silage in kid's diets reduced feed cost for every $1 \mathrm{~kg}$ gain (L.E). Therefore, the economic efficiency was noticeably better for kids who fed mixture silage $(G 2,4.08)$ compared with other treatments. Generally, it also found that using a mixture from BS and PMS in diets of growing male Zaraibi goats was the best economic efficiency, as shown in Table (8).

Table (8): Economic efficiency of Zaraibi kids fed the experimental rations

\begin{tabular}{|l|c|c|c|}
\hline \multirow{2}{*}{ Item } & \multicolumn{3}{c|}{ Treatments } \\
\cline { 2 - 4 } & G1 & G2 & G3 \\
\hline Daily feed intake (g/h) as fed: & \multicolumn{3}{c|}{} \\
\hline CFM & $\mathbf{4 6 0}$ & $\mathbf{5 0 0}$ & $\mathbf{4 7 0}$ \\
\hline BS & 1.200 & - & - \\
\hline PMS & - & - & 1.170 \\
\hline BS+PMS & - & 1.325 & - \\
\hline Av. daily DMI, g & 1.660 & 1.825 & 1.640 \\
\hline Cost of consumed feed, L.E/h & 2.440 & 2.631 & 2.447 \\
\hline Price of weight gain, L.E/h & $\mathbf{8 . 8 5 4}$ & 10.734 & 9.292 \\
\hline Feed cost/kg gain L.E & 13.78 & 12.26 & 13.17 \\
\hline Economic efficiency\%* & 3.63 & 4.08 & 3.80 \\
\hline
\end{tabular}

Economic efficiency was calculated as total output/total input according to the local prices ( where 1 ton of CFM $=4000$ L.E., berseem silage $=500$ L.E., and one ton from Panicum silage $=450$ L.E. while $1 \mathrm{~kg}$ live body weight of male Zaraibi goats sold for $=50$ L.E. (one United States Dollar $($ USD) $=15.64$ Egyptian Pound (L.E * = Price of weight gain / Cost of consumed feed. 


\section{CONCLUSION}

From the results of this experiment, it becomes clear that the use of Panicum Mombasa has a positive effect on the productive performances of kids goats, especially when mixed with different green legumes forages as an Egyptian clover, in terms of dry matter intake, digestibility and feeding value, feed conversion, daily gain and economic efficiency makes it a diet of choice for production and reproduction performance.

Further studies are needed to evaluate the Panicum Mombasa forage (hay, fresh, and silage) at the different levels as well as with other different sources of protein, energy, and some feed additives with farm animals.

\section{REFERENCES}

Adegun, M.K. and P.A. Aye (2013). Growth performance and economic analysis of West African Dwarf Rams fed Moringa oleifera and cottonseed cake as protein supplements to Panicum maximum Department of Animal Production and Health Sciences. American Journal of food and nutrition, 3(2): 58-63.

Ahmed, M.E. (2003). The economic marketing weight of male Zaraibi goats. Egyptian J. Nutrition and Feed, 6 (Special Issue): 13111324.

Ahmed, M.E. ; E.I. Shehata ; M.E. El-Kholany ; G.I. El-Emam ; E.I. Khalifa and H. Bahery (2013). Productive performance of Zaraibi goats fed berseem and/or triticale silage. The $4^{\text {th }}$ Scientific Conference of Animal Production Research Institute, 184:192.

Ahmed, M.E. ; E.I. Shehata and A.M. Abdelhamid (2000). Growth performance of male kids according to different feeding levels, concentrate to roughage ratio and diet inclusion of bentonite. Proc. 3rd all Africa Conf. Anim. Agric. \& 11th Conf. Egyptian Soc. Anim. Prod., Alexandria, 6-9 November, p: 201.

Ahmed, M.E.; A.M. Abdelhamid; F.F. Abou Amou; E.S. Soliman; N.M. El-Kholy and E.I. Shehata (2001). Response of milk production of Zaraibi goats to feeding silage containing different levels of teosinte and kochia. Egyptian J. Nutrition and Feeds, 4:141.

Ajayi Festus Tope1; Ogunleke Funmi; Adesina Adewumi and Durotoye Emmanuel Sunday (2012). Performance, Hematology and Serum Biochemistry of West African Dwarf Goats Fed Ensiled Mixtures of Elephant Grass (Pennisetum purpureum) with Lima Bean, African Yam Bean and Pigeon Pea. Kasetsart J. (Nat. Sci.), 46: 694 $-702$.

Al-Jorani, M.A.; A.S.A. Al-Obaidi and Z.T. Al-Door (2020). Effect of feeding Panicum Mombasa grass on productive traits and carcass 
characteristics of local cross breed goats. Iraqi Journal of Agricultural Sciences,51(5):1436-1447.

A.O.A.C. (1995). Official Methods of Analysis (16th Edit). Association of Official Analytical Chemists, Washington, D.C., USA.

ARC (1980). The Nutrient Requirements Of Ruminant Livestock. Commonwealth Agricultural Bureaux. Farnham Royal, Slough, UK $351 \mathrm{pp}$.

Bamigboye, F.O.; A.J. Igbekoyi and O.J. Babayemi (2014). Nutritive value of some agro-industrial by-products as supplement to guinea grass (Panicum maximum) by sokoto gudali calf. Journal of Nutrients, 1(1): 1-6.

Baraza, E.; S. Angeles; A. Garcia and A. Valiente - Banuet (2009). Adoption of silage as Methodology to improve domestic goat productivity for marginal farmers of the Tehuacan valley in Mexico. Liv. Res. for Rural Dev. 21(9). [Available from: www.lrrd. org/lrrd21/12/bara 21215.htm]. [Sourced: 6 June 2011].

Behery, H.R.; E.I. Khalifa and A. Mahrous (2014). Influence of feeding non-conventional energy sources on pubertal phases, blood metabolites and fattening of zaraibi male kids. J. Animal and Poultry Prod., Mansoura Univ., 5 (3): 127-141.

Brown, W.F. and M.B. Adjei (1995). Urea ammoniation effects on the feeding value of guineagrass (Panicum maximum) hay. Journal of Animal Science, 73(10): 3085-3093.

Du Ponte, W.M.; E. Souza ; M.C. Campbell and K.G. Fukumoto (1998). Guinea grass (Panicum maximum) silage as an alternate roughage source for subsistent dairy production. http://www.hawaii. edu/ansc/Proceed/Hhl/ggrass.httm

Duncan, D.B. (1955). Multiple Range and Multiple (F-test). Biometrice, 11: $1-42$.

Entwistle, K. (1992). A brief update on male reproductive physiology. In: Bull Fertility. R. G. Holroyd, Dd. Queensland Gov., Brisbane. P:1.

Eyoh, G.D.; M.D. Udo and C.P. Edet (2019). Growth performance and carcass characteristics of West African dwarf bucks fed different forms of processed guinea grass (Panicum maximum). Current Agriculture Research Journal, 7(2): 1-9.

Gabra, M.A. (1984). Studies on the productivity and feeding qualities of some annual and perennial forages as affected by some agronomic practices fed to sheep in metabolism trials including nutritional balances. Ph.D., thesis, Faculty of Agric., Cairo Univ., Egypt.

Gabra, M.A. and S.W. Sherif (1985). The feeding value nitrogen balance and daily intake of triticale, berseem and there mixture in metabolism trials with sheep. Annu. Agric. Sci. Moshtohor. 23, 683-693. 
Gabra, M.A.; A.M. Abdelhamid and M.Y. EI-Ayek (1991). Nutritional evaluation of dried poultry litter in comparison with berseem hay (Trifolium alexandrinum) and their mixtures as feeds for sheep. J. Agric. Sci. Mansoura Univ., 16 (9): 2004 - 2016.

Gidamins, A.B.; J.T. Panga; S.V. Sarwatt ; B.F. Chove and N.B. Shayo (2003). Nutrient and Antinutrient contents in raw and cooked leaves and mature pod of Moringa oleifera, Lam. Ecology of Food and Nutrition, 42:1-13.

Haggag M. El-H.; E.S. Soliman and M.E. Ahmed (2002) Triticale forage as a feed for sheep. Proc., 1st Ann. Sc. Conf. Anim. And fish prod, Mansoura, Sep., P: 77.

Haggag, M. El-H.; E. S. Soliman ; E.M. Gaafer and M.I. Salim (2000). Effect of phosphate fertilizer levels and seeding rates on yield, quality and nutritional evaluation of sesbania forage by goats. J. Agric. Sci. Mansoura Univ., 25 (7): 3901.

Humphreys, L.R. and I.J. Patridge (1995). A Guide to better pastures for the tropics and subtropics. Published by NSW Agriculture 5 edition: Grasses th for the tropics: Guinea grass (Panicum maximum) (Light), 8: 45-59.

Ibrahim, F.A.; E.S. Soliman; A.A. Abd El-Hamid and M.E. Ahmed (2012). Growth performance and feed utilization efficiency of Rahmani lambs fed some legume and /or grass silages. Egyptian J. of Sheep and Goats Sciences, 7 (2): 1.

Jank, L.; J.A. Martuscello; V.P.B. Euclides; C.B. Valle and R.M.S. Resende (2013). Panicum maximum. In D. M. Fonseca, \& J. A. Martuscello (Eds.), Plantas Forrageiras (2nd ed., pp. 166-196). Editora UFV, Viçosa

Jiwuba, P.C.; F.O. Ahamefule; I.P. Ogbuewu and K. Ikwunze (2017). Blood chemistry and hematology of West African Dwarf goats fed Moringa oleifera leaf meal (MOLM) in their diet. Comparative Clinical Pathology, 26(3): 621-624.

Kaneko, J.J. (1989). Clinical Biochemistry of Animals. 4thEd., Academic Press, Inc. USA.

Kheradmand, A.; H. Babaei and R.A. Batavani (2006). Effect of improved diet on semen quality and scrotal circumference in rams. Veterinarski Arhiv, 76 (4): 333-341.

Loresco, M.M.; M.J.C. Andal; K.J.S Ty and A.A. Angeles (2019). Growth Performance of Growing Dairy heifers fed fresh MULATO II (Brachiaria ruziziensis $x \mathrm{~B}$. decumbens $\mathrm{x} B$. brizantha) and MOMBASA (Panicum maximum Jacq. cv. Mombasa) Compared to NAPIER (Pennisetum purpureum Schum.). Philippine Journal of Veterinary and Animal Sciences, 45(1-3): 87-90. 
Makkar, H.P.S. and K. Becker (1997). Nutrients and antiquality factors in different morphological parts of Moringa oleifera tree. Journal of Agricultural Science, 128:311-322

Mohamed, S.S. and A.M. Abdelatif (2010). Effects of level of feeding and season on thermoregulation and semen characteristics in Desert Rams (Ovis aries). Global veterinaria, 4(3): 207-215.

Nkosi, B.D.; R. Meeske and I.B. Groenewald (2010).Effects of ensiling potato hash with either whey or sugarcane molasses on silage quality and nutrient digestibility in sheep. Livestock Research for Rural Development, 22:1-7

NRC (2007). Nutrient requirements of small ruminants: Sheep, goats, cervids, and new world camelids, National Academies Press, Washington, D.C., U.S.A.

NRC (1981). Nutrient Requirement of Goats: Angora, Dairy and Meat Goats in Temperate and Tropical Countries. National Academy of Sciences, No 15. Washington DC, USA. 93pp.

Ojo, Victoria Olubunmi A.; D. Oyaniran; A.O. Ogunsakin; R.Y. Aderinboye; O.O. Adelusi and F.S. Odusoga (2019). Effects of supplementing herbaceous forage legume pellets on growth indices and blood profile of West African dwarf sheep fed Guinea grass. Tropical Animal Health and Production, 51(4): 867-877.

Refaie, Amira M.; Walaa A. Salama ; A.E. Shams El-deen; Malak M. Beshara; F.S. Khalil and A.M. Alazab (2020). Influence of Panicum maximum Replacement of Clover Hay on the Performance of Growing Rabbits. World'sVeterinary Journal World Vet J.,10(2): 175-182.

Rosales, M. and M. Gill (1997). Tree mixtures within integrated farming systems. Livest. Res. Rural Dev., 9:4.

SAS Institute (2002). SAS/STATR User's Guide: statistics. Ver. 9.1, SAS Institute Inc., Cary, NC, USA.

Shehata, E.I.; M.E. Ahmed; A.M. Abdelhamid; Faten F. Abou Ammou and M. El-H. Haggag (2001) Comparative nutritive values of silage ration containing different level of teosinte and Kochia. Egyptian J. Nutrition and Feeds, 4: 129.

Sinclair, L.A.; P.C. Garnsworthy; J.R. Newbold and P.J. Buttery (1995). The effect of synchronizing the rate of dietary energy and nitrogen release in diets with similar carbohydrate composition and rumen fermentation and microbial protein synthesis in sheep. J. Agric. Sci. Cambridge, 120:251-263.

Soliman, A.A.; M.E. Ahmed; Faten. F. Abou Ammou; E.I. Shehata; M.K. Abou Elmaged, S.A. Tawfik and M.A. Shebl ( 2010), Impact of some feed additives on Zaraibi goats performance and 
blood profile fed aflatoxins contaminated diets. AmericanEurasian J. Agric. And Erviron Sci., 7 (1): 80.

Soliman, E.S.; A.E.M. Kinizy; Bahira K. Mohamed and M. El-H. Haggag (1997). Studies on using Sesbania and Teosinte forage in feeding of growing Zaraibi goats Egypt. J. Appl. Sci.,12 (5): 36.

Taye Olurotimi Abegunde; Festus Tope Ajayi; Joseph Folami Olona and Fatima Balogun (2017). Supplemental value of leaf based concentrates with Panicum maximum hay on performance of West African dwarf goats. African Journal of Agricultural Researc., 12(9): 723-729.

Van Soest, P.J. (1996). Environment and forage quality. Proc. Cornell Nut. Conf. Feed Manuf. P 1 Cornell Univ., Ithaca, NY.

Van-Keulen, J. and B.A. Young (1977). Evaluation of acid-insoluble ash as natural marker in ruminant digestibility studies. J. Anim. Sci., 44:282.

Wildeus, S.; J.M. Luginbuhl; K.E. Turner ; Y.L. Nutall and J.R. Collins (2007). Growth and carcass characteristics in goat kids fed grass and alfalfa-hay-based diets with limited concentrate supplementation. Sheep and Goat Research Journal, 22: 15-19.

Yousuf, M.B.; M.A. Belewu; J.O. Daramola and N.I. Ogundun (2007). Protein supplementary values of cassava-, leucaenaand gliricidialeaf meals in goats fed low quality Panicum maximum hay. Livestock Research for Rural Development, 19(2):1-6.

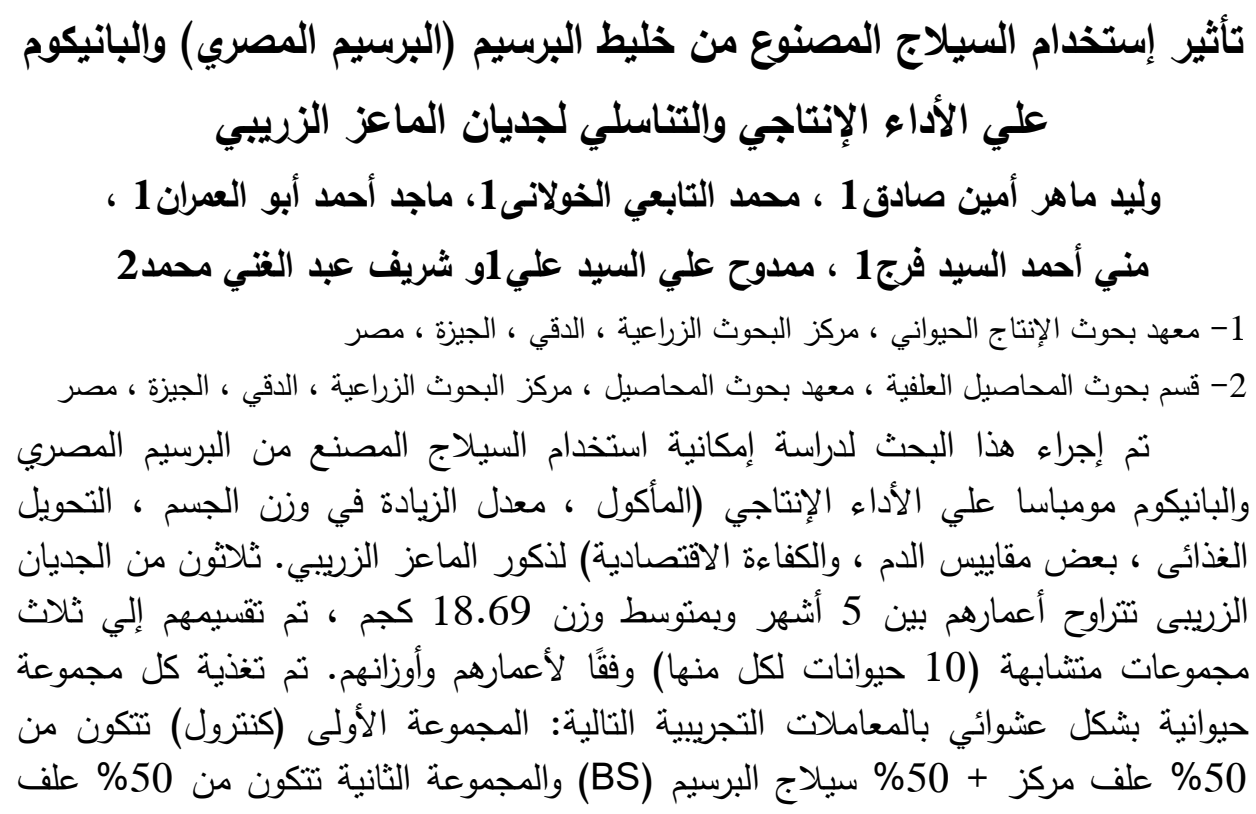


مركز + 50 \% سيلاج مصنع من (25\% سيلاج البرسيم + 25\% سيلاج البانيكوم) وأخيرا

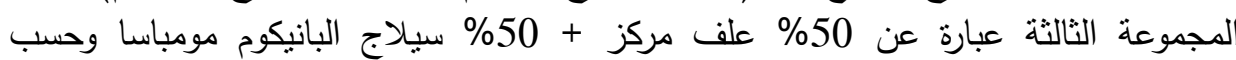

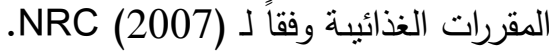

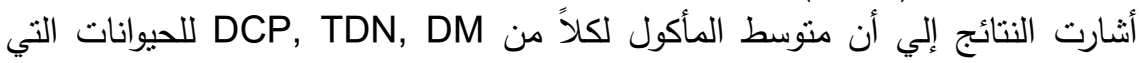

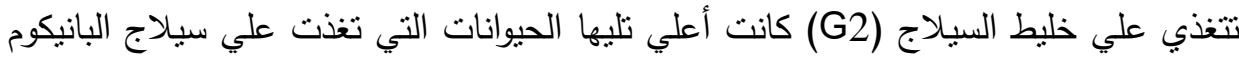

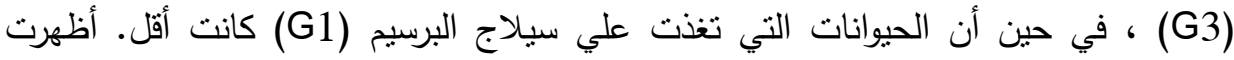

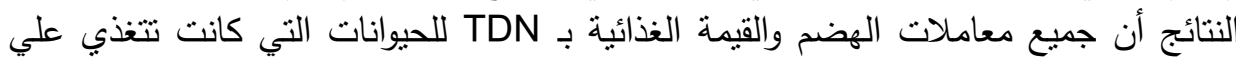
السيلاج المخلوط (GS) كانت أعلي من تلك الحيوانات التي تغذت علي سيلاج البرسيم (BS)

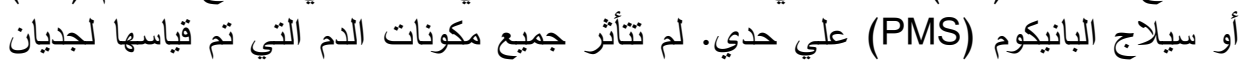
الماعز (البروتين ، الألبومين ، الجلوبيولين ، اليوريا-N ، الجلوكوز ، والكرياتينين) بالمعاملات

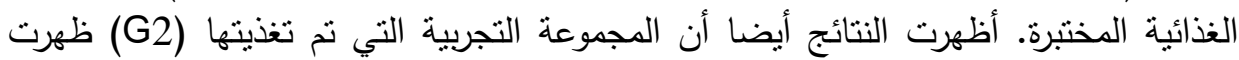

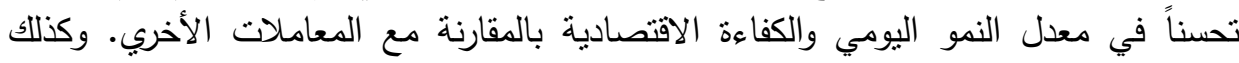

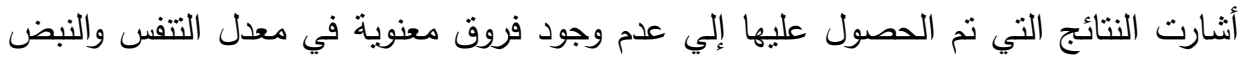

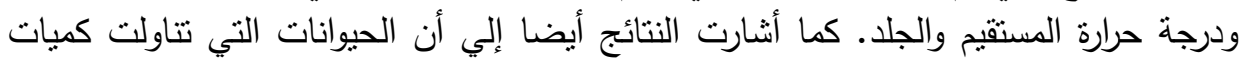

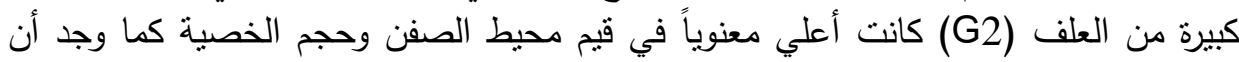

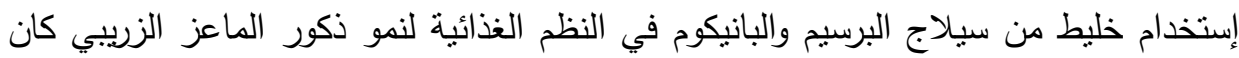
أفضل اقتصادية. يمكن الاستتناج أن استخدام البانيكوم (Panicum Mombasa) له تأثنير إيجابي علي

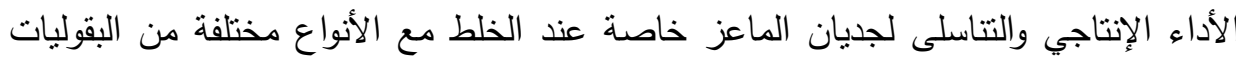

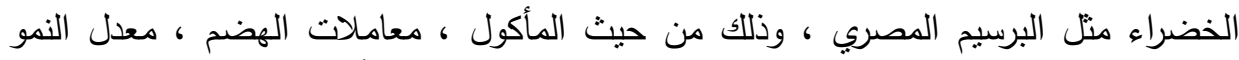

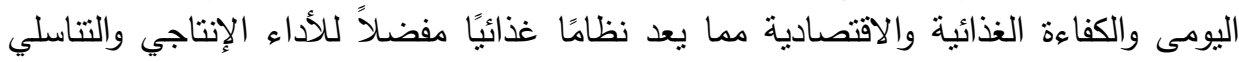

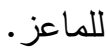

